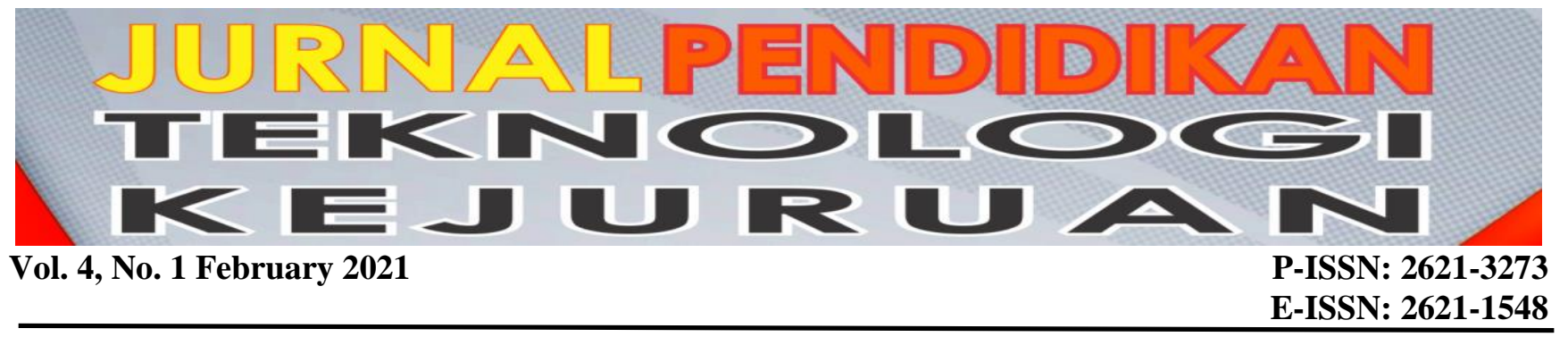

\title{
Development of Food and Beverage Service Module at Vocational High Schools Culinary Service Expertise Program
}

\author{
Ajeng Inggit Anugerah \\ Universitas Negeri Medan \\ *Corresponding author, e-mail: ajeng_inggit9@unimed.ac.id
}

\begin{abstract}
This article aims to explain about study was to develop a learning module on the subjects of Food and Beverage Service in students majoring in food services SMK Putra Anda Binjai. This study was Research and Development (R \& D) by using ADDIE development model. The results of research and development has been done in this study indicates that the validation results by learning modules covering material expert's feasibility content with value Aiken's $V=0.78$ valid criteria, eligibility presentation of Aiken's $V=0.80$ on valid criteria, aspects of language with Aiken's $V=0.8$ on valid criteria, and validation of design experts with Aiken's $V=0.80$ on valid criteria. Test practitioners learning modules to two teachers showed an average yield of 81.67 category of "very practical", while practitioners by 3 students showed an average yield of 79.32 category of Very Practical overall results of the validation by subject matter experts, expert media practitioners and the overall test states that learning modules rated valid and practical, so that used to test for effectiveness. The result of the effectiveness of the learning modules have an average pretest score is $\mathbf{5 0 . 8 3}$ while the average post-test values to 76.95 so that it can be concluded posttest value results more significant. Therefore, from the validity of the test results, the practicalities and effectiveness, then learning modules on subjects worthy Food and Beverage Service use as a source of student learning Vocational High School Programs Hospitality.
\end{abstract}

Keyword: Food and Beverage Service Module, Research and Development (R \& D), Validity, Practicalities, Effectiveness

\section{INTRODUCTION}

Improving the quality of Human Resources is one of the solutions in facing the era of globalization. The era of globalization is an era of free market competition that demands various changes in all aspects of life. With this era of globalization, schools are required to make various efforts oriented to the creation of globally competitive graduate competencies to suit the demands of the world of work, business/industry and the development of science and technology. Improving the quality of human resources through improving the quality of education.

Based on this opinion, it can be said that education is a very important factor in human life. Education is a process in building humans to develop themselves so that they can face all the problems that arise in humans themselves.
In an education, of course, it cannot be separated from learning in schools that want learning that can foster students' enthusiasm for learning. A learning course also has a specific goal to be achieved with the desired target. With this goal, it will foster an attitude that will become the teacher's grip in the learning process. The learning process in schools is the responsibility of the teacher (Islami et al., 2021).

The teaching and learning process is a process of teacher and student interaction through integrated activities of two forms of activity, namely student learning and teacher teaching activities. The teaching and learning process occurs when there is interaction between students and the learning environment arranged by the teacher to achieve teaching goals. Teachers as educators who deal directly with students must participate in paying attention to and being responsible for progress and improving student learning outcomes. Learning is a process that is 
characterized by changes in a person's self (Sudjana, 2011).

Thus, one thing that teachers can do is to improve student learning outcomes, teachers must have teaching skills and master learning models, besides that before teaching a teacher should have preparation in the form of learning tools such as syllabus, Teaching Program Design, annual program and semester and what is no less important is learning media that is easy to understand and attracts students' attention to spur students' enthusiasm to learn (Pernanda et al., 2018).

Vocational High School as a form of formal vocational education is secondary education that has a role in preparing a professional and skilled workforce in certain fields. In accordance with Law No. 20 of 2003 concerning the National Education System Elucidation of Article 15 which explains that vocational education is secondary education that prepares students especially to work in certain fields (Undang-undang sistem pendidikan nasional, 2003). One of the Vocational High School groups is the Arts, Crafts and Tourism group. Tourism group vocational schools have expertise programs, one of which is Catering Services. In the Catering Service expertise program, one of the subjects taught to students is Dishes. This course is related to service procedures in restaurants. The success of the restaurant operating depends on how the waiter prepares equipment related to the service process, both from menu design, tableware, and drinking dishes and linen.

Learning is a process of students learning and teaching teachers, where the process occurs interaction between students, teachers, methods, curriculum, facilities, and related environmental aspects to achieve learning competence. The learning process in vocational schools focuses more on practical activities than on theory, so that the existence of learning media can meet the needs of students to be able to learn independently. Therefore, the module is a learning medium that can present the needs of students to be able to learn independently.

The learning module is one of the learning media that can support the achievement of learning objectives. In delivering material in class, many students do not have modules, therefore the learning process is teacher center so that learning independence is not achieved. The independent learning process carried out by students both at home and elsewhere cannot be carried out optimally because students cannot review learning materials (Yulastri et al., 2018).
Teachers play an important role in the success of their students, even though the tools are well and complete but if the teacher is not successful in the teaching and learning process, students can receive lessons well too. Before carrying out the teaching and learning process, a teacher must determine a learning model that will be used so that the learning objectives that have been prepared can be achieved.

In this case, the teacher must be as observant as possible to adjust the learning model to the characteristics of the subject matter and the direction of the objectives to be achieved from the subject matter to be delivered. Because the use of an inappropriate learning model will be an obstacle in achieving the learning objectives that have been formulated.

The selection of learning strategies is one of the alternatives taken by a teacher in the teaching and learning process, in order to achieve learning objectives that are in line with the abilities of students. So far, teachers only use a monotonous learning model with the same kind, namely conventional learning, namely the learning process that dominates students to be passive in participating in learning activities, and sometimes they do not require tools and practice materials, it is enough to explain the concepts contained in textbooks or textbooks. another reference. Students are only used to listening, taking notes and then memorizing without the motivation to understand. This boredom and laziness of students can ultimately make student learning outcomes low. Even though at this time teachers must be able to use varied learning models in the teaching and learning process in schools. When teachers teach only using conventional methods without involving students in learning activities, students tend to be passive, then feel bored and want the teaching and learning process to be completed quickly.

Based on observations in the theoretical and practical learning process at the Putra Anda Binjai Vocational High School, there are still many obstacles faced by students. The obstacles faced include students' lack of understanding of the material delivered by conventional teaching methods and learning independence cannot be achieved optimally because students do not have learning modules so that students cannot review learning material that has been delivered at school.

In this case, the teacher has tried to apply various learning approaches, including an approach that can encourage students to find their own knowledge in understanding the material presented. This can be 
seen from the activities of some students only taking notes, students do not want to ask questions and make the teacher the only source of obtaining knowledge, so that there is not enough interaction between students and students or students and teachers. Such conditions result in low learning outcomes and student activities in learning.

Student learning outcomes in the last three years showed that students who achieved a very high level of completeness (A) in learning were $27.5 \%$, high category (A-) was $52.5 \%$, very good category $(\mathrm{B}+)$ was $97.5 \%$, good category (B) is $107.5 \%$, while the category of student achievement is not good $17.5 \%$. The data is based on a population of 120 people. The low score in the very high category (A) in the subjects of knowledge and continental food processing, learning outcomes are not optimal.

Learning is related to the plan for making learning strategies. Learning strategies are planned efforts in manipulating learning resources so that the learning process occurs in students. Learning strategy is a condition created by the teacher intentionally so that participants are facilitated in achieving the learning objectives set (Sadiman, 2012)

In the process of delivering food dishes, the teacher only uses the monotonous lecture method in explaining the material, students take notes more often. This allows boredom for students. In addition, the limitations of learning resources used by teachers in teaching are still limited, namely textbooks and handouts for students. Another obstacle faced by students is the lack of reference sources on food ordering subject books, the availability of learning resources in the form of books for food dishes in the library of SMK Putra Anda Binjai there are only 2 reference sources. So that other learning resources are needed to assist the learning process in order to increase the insight and knowledge of teachers and students. Utilization of learning resources also aims to develop an interesting teaching and learning process. The interesting thing that can be found when teachers use learning resources is the existence of many-way interactions, namely between students and students, students and teachers.

One of the learning resources that can be used is the module. The selection of this module is adjusted by taking into account the characteristics and abilities and conditions of the school. Modules are teaching materials that contain materials, methods, limitations, and evaluations that are arranged systematically and attractively.
The focus in this research is the development of learning modules for food dishes in the learning process in class XI Catering Services. With that, to support learning activities in the subject of Dishes, students are expected to be able to learn independently by using learning media in the form of a developed module. By making this module, students are expected to better understand the operational activities of a waiter in providing services to guests before the restaurant is opened until the restaurant is closed. So that the competencies that have been set are achieved properly.

\section{METHOD}

The type of research that will be conducted is development research. This research belongs to research that produces products to improve low learning outcomes. The development model used is the ADDIE model. ADDIE is an abbreviation that refers to the main processes of the learning system development process, namely: Analysis, Design, Development, implementation, and Evaluation. This research is expected to help improve the low grades of students in the subject of Dishes at SMK Putra Anda Binjai.

The instruments developed to collect data in this study are as follows:

\section{Validation Sheet}

The validation sheet is intended to determine the validity of the module media with the subject of Cuisine by experts. Before conducting the research, the writer arranged the instrument based on the instrument grid. The scale used in compiling the validation instrument in this study is a Likert scale where on this scale the variables to be measured are translated into variable indicators. Then the indicator is used as a benchmark for compiling instrument items which can be in the form of statements or questions. The answer to each instrument item using a Likert scale has a gradation from very positive to very negative.

\section{Practicality Sheet}

The module practicality questionnaire sheet consists of sheets to measure the practicality level of the module media for teachers and students. In preparing this practicality, the steps are the same as the preparation of the validation sheet described above. This practicality instrument is also arranged using a Likert scale.

\section{Effectiveness Sheet}

Effectiveness is seen from the results of the learning test using the Dishes learning module. Learning outcomes are obtained by giving tests to local students who have been given learning treatment using valid and practical learning modules. The value 
of student learning outcomes obtained from each student is converted into an initial value with a range of $0-100$. The standard applied as an indicator of success in learning outcomes is a minimum of 70 (Hake, 1999).

The data analysis technique used in this research is descriptive data analysis technique. That is by describing the validity, practicality and effectiveness of using the Dish-Ordering learning module.

\section{RESULT}

The process of implementing the development of the Catering Service learning module for learning Dishes is carried out in stages. The first stage is to analyze the problems and needs at SMK Putra Anda Binjai which is the background of the development research problem by distributing questionnaires to 2 teachers and 40 students at the school by first outlining the definition of problem-based teaching materials in the questionnaire in order to have an overview of the questions in the questionnaire. the questionnaire submitted.

The search results from the questionnaire found that $100 \%$ of the teachers stated that they needed a learning module in the learning process so that the learning process runs more effectively and $100 \%$ of the students stated that they needed the Catering Service learning module, especially on the Dishes, so that the learning process runs more effectively and so that it can be used as a learning tool. by students as a means of individual learning.

The level of effectiveness of student learning outcomes after using the Cuisine Learning Module was analyzed by looking at the level of achievement of student learning outcomes in the Dishes lesson, by adding up the scores of student learning outcomes.

The results obtained from 40 students who were taught by learning modules in the Dishes lesson, as many as 3 people $(7.5 \%)$ got the very effective category, 17 people $(42.5 \%)$ got the effective category, 15 people $(37.5 \%)$ got the quite effective category and 5 people $(12.5 \%)$ got the less effective category. Thus, it can be concluded that the Dishes Learning Module used in improving student learning outcomes for class X catering services at SMK Putra Anda Binjai is in the Effective category with a gain score of 0.53 with moderate criteria.

\section{DISCUSSION}

Research and development is carried out with the aim of producing products in the form of teaching materials for Tata Hidang as well as testing the effectiveness of products that can be used by Class $\mathrm{X}$ Catering students at SMK Putra Anda Binjai as one of the ways to improve the quality of learning. Therefore, the research and development process is carried out and begins with several stages, including (1) Conducting a preliminary study through observation and literature study. From the results of observations obtained data that students really need teaching materials in the form of modules. (2) Designing products to produce the initial product of teaching materials. (3) Develop teaching materials. These activities include introduction, SK and KD, learning activities, and bibliography (4) Design of learning activities includes learning materials, summaries, tests, and answer keys. (5) Validating and revising, this activity includes product evaluation to find out the strengths and weaknesses regarding the quality of content and design carried out by material experts and design experts. The results of the evaluation will be used as material for product revision. (6) Conducting individual trials, small group trials, and limited field trials so as to produce teaching materials in the form of Dishes learning modules for class XI Catering Services SMK Putra Anda Binjai which are suitable for use.

The validation results from material experts in the development of Catering Services teaching materials in the form of narrative essay modules for students show that the feasibility of content with Aiken's V score of 0.77 on valid criteria, presentation feasibility with Aiken's V value of 0.78 on valid criteria, and language feasibility with Aiken's V 0.80 on the valid criteria. Thus, problem-based teaching materials in the form of modules developed as a whole are included in the "valid" criteria.

The results of validation from design experts on the feasibility of design in the development of teaching materials in the form of learning modules for dishes for students that were developed showed that the size of the module had an Aiken's V value of 0.92 on valid criteria, module cover design with Aiken's V of 0.83 on valid criteria, and module content design with Aiken's V 0.8 on valid criteria. The results of the validation of all sub-components of the design feasibility assessment are 0.85 with "valid" criteria. Thus, the feasibility of designing teaching materials for writing narrative essays in the form of modules developed can be used as a design pattern that students will use.

The results of the data obtained from the teacher, stated that the teaching material was in the form of a Dishes learning module for students of class XI 
Catering which was developed in accordance with the assessment indicators in the overall statement with an average of $81.67 \%$ on the "very practical" criteria. This is in accordance with the results of Gagne's research which states that the best teaching materials in the world will not fulfill their functions and roles if the teaching materials are not liked by a teacher (Gagne, R \& J., 1974).

The data obtained from the students that the teaching materials are in the form of the Dishes learning module developed in accordance with the assessment of the indicators in the overall statement indicate that (1) the average percentage of individual trials is $79.32 \%$ with "practical" criteria, ( 2) the average percentage of the small group trial is $81.48 \%$ with the "very practical" criteria, and (3) the average percentage of the limited field group test is $86.18 \%$ with the "very practical" criteria. The data on the results of student responses to the developed module has increased, namely an increase of $2.16 \%$ from individual trials to small group trials, and an increase of $4.7 \%$ from small group trials to limited field group trials.

A teaching material is considered final after showing satisfactory results in achieving predetermined goals. For this, it is necessary to test the product in the learning process to determine the effectiveness of the product (Yulastri et al., 2017). To see the effectiveness of the product, an analysis of learning outcomes was carried out on 40 students who were taught using the developed teaching materials and compared with the learning outcomes of students who were taught by textbooks. Based on the analysis, the average score on basic competencies using teaching materials for Dishes is higher with an average of 76.95 than the average score of students before using teaching materials in the form of modules with an average of 50.83. So that it can be stated that there are differences in learning outcomes between students who use Catering Services teaching materials for learning Dishes with a gain score value of 0.53 with moderate criteria and it is concluded that the teaching materials developed are effective and suitable to be used as learning resources.

\section{CONCLUSION}

Research on the development of the Catering Service Learning module for cooking food learning was developed using the ADDIE model, which consists of the analysis, design, development and evaluation stages.

The Catering Services Learning Module product for Dishes learning which was developed on the Dishes material for class XI Catering Services SMK Putra Anda Binjai students meets the requirements and is suitable for use based on material expert validation including content feasibility with Aiken's $\mathrm{V}$ value = 0.77 on valid criteria, presentation feasibility Aiken's $\mathrm{V}=0.78$ on the valid criteria, the language aspect with Aiken's $\mathrm{V}=0.8$ on the valid criteria, and design expert validation with Aiken's V $=0.85$ on the valid criteria.

The practicality of using the learning module in the Dishes subject in the Catering Department at SMK Putra Anda Binjai seen from the teacher's test got a very good score of $81.67 \%$. The pattern of the Catering Learning Module for the Class XI Catering Services subject for the Catering Services at SMK Putra Anda Binjai has very practical criteria with a percentage of $86.18 \%$.

The learning outcomes of students who were taught using the Dishes learning module were higher than the learning outcomes of students who were taught without using the Dishes learning module. The effectiveness of the use of learning modules in the Dishes subject in the Catering Department at SMK Putra Anda Binjai shows that student learning outcomes are in the Effective category of $42.5 \%$ and the gain score value is 0.53 in the medium category.

\section{REFERENCES}

Gagne, R, M., \& J., B. L. (1974). Principle of Instructional Design. Holt, Rinehart \& Winston.

Hake, R. R. (1999). Analyzing Change/Gain Scores. Dept. of Physics, Indiana University 24245.

Islami, S., Candra, O., Usmeldi, Sartiva, W., \& Imelda, Z. (2021). Implementation of the tournament-type method of learning in basic electrical installation subjects. In Borderless Education as a Challenge in the 5.0 Society. Taylor \& Francis Group.

Undang-undang sistem pendidikan nasional, (2003).

Pernanda, D., Zaus, M. A., Wulansari, R. E., \& Islami, S. (2018). Effectiveness of instructional media based on interactive cd learning on basic network at vocational high school: improving student cognitive ability. International Conference on Education, Social Sciences and Technology, January, 440-444. https://doi.org/10.29210/2018163

Sadiman, A. (2012). Media pendidikan pengertian, pengembangan dan pengembanngan dan pemamfaatanya. Rajawali Press.

Sudjana, N. (2011). Penilaian Hasil Proses Belajar Mengajar. PT. Remaja Rosdakarya. 
Yulastri, A., Hidayat, H., Ganefri, G., Edya, F., \& Islami, S. (2018). Learning outcomes with the application of product based entrepreneurship module in vocational higher education. Jurnal Pendidikan Vokasi, 8(2), 120. https://doi.org/10.21831/jpv.v8i2.15310

Yulastri, A., Hidayat, H., Ganefri, Islami, S., \& Edya, F. (2017). Developing an Entrepreneurship Module by Using Product-Based Learning Approach in Vocational Education. International Journal of Environmental \& Science Education, 12(5), 10971109. 